\title{
On Being Jewish at a Jesuit University: Reflections on Organizational Cultures
}

\author{
William A. Gamson ${ }^{1}$
}

This article provides reflections on the intersection of religion, identity, occupation, and organizational culture as it occurred in my professional life.

KEY WORDS: insiders and outsiders; Jewish identity; occupations; organizational culture; religion.

\section{INTRODUCTION}

It's 1981 and Zelda and I are professors at the University of Michigan. We've been living in Ann Arbor since 1962 and our children are off in college and the world. For various personal reasons, the Boston area beckons and we are actively looking for jobs there. I hear about an interesting possibility at a school about which I am only superficially aware-Boston College.

I visit the university and the sociology department to explore the possibility. I have a few acquaintances there from previous professional contact but no close friends. A lot is going on that I find interesting and stimulating and I am sensing an increasingly good fit. My concerns and questions about the broader university culture center on issues of academic freedom. Will I find any restrictions on my freedom to teach and pursue research on politically sensitive issues such as abortion where the Catholic Church may have strong positions?

Midway during my visit, I meet with some of my potential future colleagues in the political science department. During one such discussion, a young political scientist, Kay Schlozman, offers to give her perspective on what it is like being Jewish at Boston College. Thus prompted, I ask her: "What's it like being Jewish at a Jesuit university?" I can't trust my memory to quote her response but my recollection is one of being reassured that I wouldn't be discriminated against or treated differently, even though I would never be an "insider."

${ }^{1}$ Sociology Department, Boston College, 5 Boston Hill Road, Chilmark, Massachusetts 02535, Email: gamson@bc.edu. 
Many years later, after more than a quarter-century of being Jewish at a Jesuit university, she and I both recognize how much that answer left out. It is true that I have not experienced any of the possible negatives that I feared. No discrimination, no interference with my academic freedom even though I was part of a collaborative research project stretching over many years on the shaping of abortion discourse in the United States and Germany. I used the abortion issue in my teaching as well, to illustrate concepts of media framing.

I have not always been happy about the way the university administration at Boston College has handled certain issues - especially those concerned with gay and lesbian groups on campus. But the sociology department has a number of GLBT Ph.D. students and they have been free to pursue the research questions that interest them without any overt or covert pressure. In sum, the reassurances about academic freedom that I received during my initial visit to Boston College turned out to be quite accurate.

What I did not really anticipate is the ways the organizational culture of Boston College would contribute positive support for my professional identity and work. This has much more to do with the type of value-engaged sociology that I do than with being Jewish but, as I will describe below, the latter is welcomed as well. But the separation is artificial in this case since the issues and questions that I have pursued in my professional life are connected in a fundamental way with being Jewish.

My work at the University of Michigan was also value engaged, but there I felt more tolerated and allowed to do it than encouraged. Social science, in the dominant norm, should be value free; using it to support activists engaged in the pursuit of justice is allowable if one meets professional standards in carrying it out. This is a type of applied sociology but contributions in this realm do not rank as high as basic research.

I believe in the professional standards of my discipline and studiously observe them in my research. More importantly, I paid my dues by publishing articles in mainstream journals and writing books that were cited by other social scientists in their research. It was a bargain I could live with and I assumed-correctly - that I would be expected to continue doing this at Boston College.

It's the early 1980s, and BC is still in the beginning stages of its quest to become the leading Catholic research university. I know the world of research universities from my years at the University of Michigan and, earlier, at Harvard. But I am attracted by the fact that the BC sociology department has a graduate training program in social economy and social policy that actively encourages connecting our knowledge and ideas with action to promote social justice. Some of the grad students are former activists with hopes of combining this with more academic work. Many of the existing faculty members do conventional, value-neutral work, but there is a lively cluster of faculty with an interest in doing more value-engaged social science. 
In terms of ethnic/religious background, the sociology faculty members are diverse. Most are clearly secular, several of Jewish background like myself; among those who were raised as Catholics, some continue to observe the faith, but as "cafeteria Catholics" who look at official doctrine critically. And I learn of a new category - "recovering" Catholics. Some of my colleagues react with intense emotion to various speeches or church actions that seem bland or even benign and well intentioned to me. I sometimes find myself in the anomalous position of defending the Pope against Catholic critics. Being Jewish, at this point, seems of little salience or relevance to my life at the university.

\section{My High Holidays Dilemma}

I have only been teaching at $\mathrm{BC}$ for a few years when the Jewish holidays of Rosh Hashanah and Yom Kippur occur on days when I have classes scheduled. The academic calendar, of course, provides a break for the Easter holiday, including Thursday through the following Monday, but Jewish holidays are - not surprisingly - ignored. How should I handle the situation?

If I choose to call off my classes those days to observe the Jewish high holidays, I have no doubt that my decision will be fully accepted and respected. If I had any doubt on this score, I would have asserted my right to do so. However, if I call off my classes, I will feel obligated in good conscience to attend services on those days instead - as well as fasting on Yom Kippur. I do not belong to a Jewish congregation and have not attended such services for many years. ${ }^{2}$ Hence, it seems hypocritical to me to call off my classes those days.

My solution is to hold my classes but to acknowledge the holidays ahead of time and to provide a convenient makeup for students who wish to observe them. No one takes me up on the offer but a few Jewish students privately express appreciation for having the option. I feel comfortable and relieved of a sense of obligation to find an appropriate congregation to attend services.

Two social movements of the 1980s engaged not only my own interests and commitments but also those of many of my colleagues and graduate students - the nuclear freeze campaign and the Central American solidarity movement against U.S. military intervention. Being at Boston College, I am soon led by colleagues to Catholic writing on just war and proportionality and to the Bishops' Pastoral Letter-published in May 1983-on the Challenge of Peace. Similarly, while I was aware of the Conference in Medellin, Columbia, that had taken place in 1968, I had not read any of the literature on liberation theology. Lo and behold, far from being a damper on my social justice concerns, Catholic and, more specifically, Jesuit thought turns out to be in the forefront of efforts to achieve social justice in a world free of the threat of nuclear war.

2 I currently belong to the Martha's Vineyard Hebrew Center-the first congregation I have ever joined - and usually do attend some services during the high holidays. 


\section{COMPARING ORGANIZATIONAL CULTURES}

My interest in the Central American solidarity movement begins in my days at the University of Michigan and illustrates the uneasy nature of my bargain with this more mainstream organizational culture. It is the late 1970s and I am spending a lot of my time in Ann Arbor at the Center for Research on Social Organization, brilliantly led by the late Charles Tilly. The center is located in a former elementary school building adjacent to major traffic arteries. This building has certain unintended spatial benefits. One must pass through public spaces and smaller bays to get to more private spaces; there are always conversations in progress among graduate students and faculty who hang around.

Many of these conversations focus on the wrongs of U.S. policy in Central America, reflecting the emerging Central American solidarity movement. Before long, another spatial advantage of the building comes into play: many of the offices have high-ceilinged, schoolroom windows, excellent for posting signs that can be readily seen by motorists driving by. These windows practically call out: "This space available for political messages."

The first signs that appear in these windows say: "U.S. Out of El Salvador." A few weeks after they appear, we hear a rumor that one or more people have called the university administration to complain that the university is "taking a political position." University officials have apparently passed on these complaints and suggested that the signs are a misuse of university property and a violation of university policy. No threats have been made as far as we know and we are left to decide what to do about the complaints.

This sparks a lively discussion, with two solutions proposed, to be implemented as each separate set of office users decides. The liberals opt for adding, in tiny letters at the bottom of each window sign, a disclaimer: "Does not necessarily represent the views of the University of Michigan." The radicals take down their signs and put up a new one, of equal size, reframing the issue as: "U.S. Out of North America." We hear no more complaints.

Flash-forward to 1989. I have been involved with many colleagues and graduate students at Boston College in the campaign against U.S. interventions in El Salvador and Nicaragua. Then, on November 16, I receive the shocking news of the murder of six Jesuits and their housekeeper and her daughter in their residence at the University of Central America in San Salvador. As we learn later, the orders to the military had been to leave no witnesses.

As one can imagine, this incident is an especially painful one for many of my colleagues at Boston College who strongly identify with the victims and, in some cases, knew them personally. For me, it is a moment of shared values and solidarity and a sense of positive support and community that I had not anticipated. Insider versus outsider distinctions do not seem very relevant and I feel more in harmony with the culture of Boston College and less ambivalence 
than I felt at Michigan. My experience with the nuclear freeze movement has a similar trajectory.

In my earlier experiences at the University of Michigan, my involvement in the peace movement sometimes brought me into conflict with the university administration. It's 1969, after the tumultuous events of the previous year - the raising, then dashing of hopes on an emotional roller-coaster, ending with the election of Richard Nixon. The antiwar movement is in a reflective mode about what has happened and what to do next.

Conversations in my circles focus on the ways that our own university is complicit in supporting the war. Many faculty members, including me, are aware of and disturbed by the fact that there is a large body of classified research being conducted for the Department of Defense at the University's Willow Run Laboratory.

Antiwar faculty and students take up the issue of banning classified research at the University of Michigan. The issue, we recognize, goes beyond sentiments about the war. Many who are ambivalent about the war share the value that conducting research, the results of which cannot be published and are available only to the sponsor, violates important values of transparency in research. The protests begin to gather momentum and the university administration responds in time-honored fashion by agreeing to create a classified research committee that will review proposals and disallow any "for which the foreseeable purpose is to destroy human life."

The anti-classified-research movement agrees to this and, as part of the agreement, submits some names, including my own, to be included on the committee. Since several of us on the committee will not have security clearance, the agreement also contains a provision that classified projects must include a nonclassified abstract, describing the research in general terms.

There are only a couple of antiwar faculty and three antiwar graduate students on the classified research committee of 15 , and only one of us is an engineer or natural scientist. We are asked to observe confidentiality about the proceedings, to which we all agree. We nonscientists ask lots of questions and there are often helpful explanations. Many of the projects raise no particular concerns about being directly related to the taking of human life.

But it turns out that there is one area of sharp disagreement. The university is a leader in the field of remote sensing. This involves the development of technologies that allow one to detect, from an airplane or helicopter, the nature of movement in the jungle at night. The machines involved can allow one to distinguish, for example, whether the moving object is metal or is carrying metal. Furthermore, the nonclassified abstracts indicate that the research is intended to improve target identification.

Along with the other antiwar members on the committee, I insist that this research does indeed have the foreseeable purpose of aiding in the taking of human life and should be disapproved. The supporters insist that the project is really basic research and that the language about target acquisition is mere boilerplate to sell it to the sponsor. On repeated occasions, we end up with 
projects being approved in a split vote, in which our group is a consistent minority.

By the end of the fall semester, I am feeling very unhappy. I feel I am aiding in the continuation of classified research that would appall my colleagues who accepted the earlier agreement in good faith. But I can't tell them about it because I had agreed earlier to treat our deliberations as confidential. I spend a lot of time in the break between semesters pondering what to do.

Toward the end of the break, I make a decision. Of the conflicting obligations between honoring my confidentiality agreement and making my colleagues aware of what was actually happening, the latter has priority. I draft a letter to the editor of the Michigan Daily and the Ann Arbor News describing what is going on in some detail and it is published in both newspapers.

As the new semester begins, the classified research controversy is back on the agenda in the university community. Shortly after classes have begun, the classified research committee has its first meeting. I walk in jauntily, giving everyone friendly "Happy New Year" greetings and receiving mostly dirty looks and silence in return. My allies on the committee privately thank me for what I have done.

The classified research story ends shortly thereafter with what feels like a hollow victory for the antiwar movement. The university decides to spin off the Willow Run Laboratory, making it independent, although some of the researchers will retain appointments in university departments as well. Technically, the university is no longer complicit but the research continues.

When I arrive at Boston College in 1982, the Cold War is at its height and the U.S. president is calling on the citizenry to confront the "evil empire." The nuclear freeze movement, launched by the late Randy Forsberg's "Call to Halt the Nuclear Arms Race" in 1980, is gathering momentum with a creative mobilization campaign. Near the end of the academic year, the Bishops' Pastoral Letter on nuclear war is released. It had been drafted by the late Cardinal Joseph Bernardin, whom I discover is a special hero to many of my newly acquired colleagues. The Catholic Church, far from being an obstacle to my political engagements, is again turning out to be in the vanguard.

Through my professional work, I have become involved in an interesting enterprise, sponsored by the National Research Council-a "Committee on the Contributions of the Behavioral and Social Sciences to the Prevention of Nuclear War." This impossibly long name is abbreviated to a cheery "Nuclear War" greeting by the receptionist who fields phone calls to the Washington office. The committee, with a lot of nationally prominent social scientists, holds various conferences and activities, including several meetings with Soviet counterparts. We have a major meeting in Estonia, followed by visits to St. Petersburg and Moscow, and also meet in San Francisco and other places. Much of the focus is on developing the idea of common security and its applications.

My involvement in the work of this committee is as welcome at $\mathrm{BC}$ as it would have been at Michigan. Boston College is, in spite of its misleading 
name, a research university with one-third of its total student enrollment in graduate and professional degree programs. Serving on an NRC committee earns one points in the currency of research universities. But, it is no longer quite the same bargain as at Michigan; in the organizational culture of BC it is an opportunity to earn double points - to earn research university points while simultaneously engaged in doing social justice activities.

Sociologists of social movements talk about them as having an "emotional culture." One is expected to be righteously indignant about certain things and excited and hopeful about others. Being part of a movement is, among other things, sharing its emotional culture. Similarly, organizations have emotional cultures. The emotional culture of most institutions of higher education is usually one of disengagement. During the peak years of these movements in whose emotional culture I shared, I felt fortunate to be located in an institutional culture in which engagement was welcomed and appreciated.

Would I have encountered the Catholic ideas and writing if I had remained at the University of Michigan? Perhaps I would have-given their salience during the height of these two movements - but they would have been at the margin of the discourse rather than at the center as they were at Boston College. I found myself assigning some of them in an undergraduate course on social conflict, naively thinking that their origins would be a selling point in an undergraduate student body that is $80 \%$ Catholic.

It may have been for some, but I found to my amusement and mild dismay that any Church imprimatur was a source of suspicion to some who saw in it an attempt at indoctrination. Once again, I found myself as a secular Jewish professor defending church writings to skeptical "recovering" Catholics, asking them to consider the ideas on their merits regardless of their source.

\section{Becoming More Jewish}

Of all the surprises awaiting me at Boston College, none could come close to the following: that it would be a place where I would deepen my - admittedly shallow - knowledge of Jewish thought and traditions. I was born in 1934, the year after Hitler came to power. Although I was not personally touched by the Holocaust, it was part of my cultural background growing up. As an avid reader of Holocaust literature, including accounts of the fate of Jewish kids of my age cohort born in Europe, I was repeatedly confronted with the inevitable thought of "there but for the grace of God go I."

As I reflect on my professional interests, it is clear to me that they are rooted in an attempt to understand the inexplicable - how the Holocaust could have happened. As I became a social scientist, my professional interest turned to social movements directed against injustices. The question of Jewish and Gentile resistance and the lack of it was a central-albeit implicit-issue. During the 1970s, I conducted research described in Encounters with Unjust 
Authority (Gamson et al., 1982). In this book, I specifically examine the process and mechanisms involved in resisting an unjust authority, comparing groups that successfully resisted with those that didn't.

Reading Helen Fein's award-winning 1979 book Accounting for Genocide helps bring to the foreground those Holocaust issues that have been implicit in my work. At Boston College, I begin developing teaching resources relevant to genocide and incorporating it into my undergraduate course on social conflict.

By 1993, Bosnia and Rwanda are happening. In the previous decade, the social science community had mobilized around the issue of preventing nuclear war amidst a runaway arms race. That particular cause is less acute in the post Cold War period we are in, but genocides are happening before the eyes of the world. Is a similar social science mobilization possible around the cause of preventing genocides?

It happens that I am, at that moment, presented with an unusual opportunity. I have been elected President of the American Sociological Association and am responsible for the theme and planning of the annual meeting to be held in the summer of 1994. The ASA Executive Officer and staff are warm supporters of the ASA playing a leadership role in an interdisciplinary "Initiative on Genocide and Human Rights." I enlist Helen Fein to help provide the intellectual leadership. She had started the Institute for the Study of Genocide in 1982 and, in addition to her theoretical and analytic contributions to the understanding of genocide and other gross violations of life integrity rights, she is networked.

During this period, I learn that Helen is planning to move from New York to the Boston area. My own university seems like an ideal base for a continuing initiative on preventing genocide. I manage to arrange an appointment for Helen as a visiting professor for the spring semester, 1994. I find much interest in this initiative among my colleagues in several departments, especially theology and philosophy, where many of the remaining Jesuit faculty members are situated. Although my efforts at arranging a permanent appointment for Helen at Boston College do not work out for complicated reasons, the interest in the topic and the informal network of faculty continue to have occasional meetings.

Near the end of the 1997-1998 academic year, the Jesuit Institute sponsors a public discussion entitled "The Holocaust: Remembering for the Future." It stimulates the interest of faculty members from various departments to have a continuing faculty seminar to "continue the discussions with a collaborative analysis of the present state of Jewish/Christian relations and of the theologies by which each community understands itself and its relationship with the other.",3

By the fall of 2000, with the aid of a generous gift, the university establishes a Center for Christian-Jewish Learning. The faculty seminar continues-meeting

${ }^{3}$ Quotation is from the website of the BC Jesuit Institute. 
for lunch about once a month during the academic year - and I continue to attend, albeit not as regularly as in the past. There is typically a reading circulated in advance and these often lead me into new issues that I haven't thought about before.

The composition of the seminar participants varies from year to year, including some visiting scholars and newcomers, but there are quite a few multiyear attendees. Generally, there is a good mix of the following four categories: Catholic scholars and theologians, lay Catholics, Jewish scholars and theologians, and secular Jews. For me, it is a time of listening and asking questions as I encounter unfamiliar discourses.

One year, partly at my urging, we choose to focus on the similarities and differences between Catholic and Jewish social justice traditions. I hear presentations and read about Tikkun Olam ("to repair the world") and the differences between tzedek ("justice") and tzedaka ("charity")- sometimes conflated and sometimes distinguished. The Catholic writings and analyses of the various gospels are, of course, new to me but the Jewish writings are often equally so.

Today, I find myself attending a variety of discussions at the Martha's Vineyard Hebrew Center about Jewish thought on a variety of topics and going to more services in any given year than I had during the first 60 years of my life. Perhaps I would have followed this route independently of Boston College, attracted by the community of people involved and a reconstructionist Rabbi, Caryn Broitman, who combines spiritual, intellectual, and political interests in a creative way, and sponsors thoughtful dialogues about issues on which there are long and complicated discussions in traditional Jewish texts. But on many topics, my interest was initially stimulated by ideas and reading that I first encountered in the Seminar on Christian-Jewish Learning.

Jewish life during the first century of the Common Era (known to me earlier as A.D.) has become much more vivid to me as I developed a deeper sense of the historical and political context in which the various Christian gospels were written. I genuinely believe that my late developing interest in Jewish thought and early history was nurtured by the organizational culture in which I do my professional work. That it was a Jesuit university that facilitated this deepened interest in Jewish thought is one of life's charming ironies.

\section{REFERENCES}

Fein, Helen. 1979. Accounting for Genocide. Chicago, IL: University of Chicago Press.

Gamson, William A., Bruce Fireman, and Steven Rytina. 1982. Encounters with Unjust Authority. Homewood, IL: Dorsey. 